University of Nebraska - Lincoln

DigitalCommons@University of Nebraska - Lincoln

Publications, Agencies and Staff of the U.S.

Department of Commerce

U.S. Department of Commerce

2011

\title{
Eddies as offshore foraging grounds for melon-headed whales (Peponocephala electra)
}

\author{
Phoebe A. Woodworth \\ National Oceanic and Atmospheric Administration \\ Gregory S. Schorr \\ Cascadia Research Collective \\ Robin W. Baird \\ Cascadia Research Collective \\ Daniel L. Webster \\ Cascadia Research Collective \\ Daniel J. McSweeney \\ Wild Whale Research Foundation \\ See next page for additional authors
}

Follow this and additional works at: https://digitalcommons.unl.edu/usdeptcommercepub

Part of the Environmental Sciences Commons

Woodworth, Phoebe A.; Schorr, Gregory S.; Baird, Robin W.; Webster, Daniel L.; McSweeney, Daniel J.; Hanson, M. Bradley; Andrews, Russel D.; and Polovina, Jeffrey J., "Eddies as offshore foraging grounds for melon-headed whales (Peponocephala electra)" (2011). Publications, Agencies and Staff of the U.S. Department of Commerce. 333.

https://digitalcommons.unl.edu/usdeptcommercepub/333

This Article is brought to you for free and open access by the U.S. Department of Commerce at DigitalCommons@University of Nebraska - Lincoln. It has been accepted for inclusion in Publications, Agencies and Staff of the U.S. Department of Commerce by an authorized administrator of DigitalCommons@University of Nebraska - Lincoln. 


\section{Authors}

Phoebe A. Woodworth, Gregory S. Schorr, Robin W. Baird, Daniel L. Webster, Daniel J. McSweeney, M. Bradley Hanson, Russel D. Andrews, and Jeffrey J. Polovina 


\section{Notes}

MARINE MAMMAL SCIENCE, **(*): ***_*** (*** 2011)

2011 by the Society for Marine Mammalogy

Published 2011. This article is a US Government work and is in the public domain in the USA.

DOI: $10.1111 / \mathrm{j} .1748-7692.2011 .00509 . x$

Eddies as offshore foraging grounds for melon-headed whales

(Peponocephala electra)

Phoebe A. Woodworth

Pacific Islands Fisheries Science Center,

National Marine Fisheries Service,

National Oceanic and Atmospheric Administration, 2570 Dole Street,

Honolulu, Hawaii 96822, U.S.A.

E-mail: phoebe.woodworth@noaa.gov

GREGORY S. SCHORR

ROBIN W. BAIRD

DANIEL L. WeBster

Cascadia Research Collective,

218 1/2 W. 4th Avenue,

Olympia, Washington 98501, U.S.A.

DANIEL J. MCSWEENEY

Wild Whale Research Foundation, P. O. Box 139,

Holualoa, Hawaii 96725, U.S.A.

M. BRADLEY HANSON

Northwest Fisheries Science Center,

National Marine Fisheries Service,

National Oceanic and Atmospheric Administration,

2725 Montlake Boulevard East,

Seattle, Washington 98112, U.S.A.

Russel D. ANDREWs

School of Fisheries and Ocean Sciences,

University of Alaska Fairbanks and Alaska SeaLife Center,

301 Railway Avenue,

Seward, Alaska 99664, U.S.A.

JefFrey J. Polovina

Pacific Islands Fisheries Science Center,

National Marine Fisheries Service, 


\section{National Oceanic and Atmospheric Administration, 2570 Dole Street, Honolulu, Hawaii 96822, U.S.A.}

Movements of upper trophic level predators in an open ocean environment should be driven, in part, by the distribution, density, and movements of their prey. Surveys have shown that cetacean densities are higher closer to shore around the main Hawaiian Islands than in offshore waters (Barlow 2006), presumably reflecting increased productivity or spatial and temporal predictability of prey associated with island effects (Baird et al. 2008a). A number of high trophic level pelagic species have been shown to concentrate around and/or use mesoscale eddies as foraging habitat (e.g., Davis et al. 2002, Seki et al. 2002, Bakun 2006, Polovina et al. 2006, Yen et al. 2006). The islands, and their interaction with winds and currents, create a complex system of eddies that may also concentrate some prey types farther offshore (Seki et al. 2002), but whether island-associated cetacean populations use these offshore eddy systems for foraging habitat is unknown.

Melon-headed whales (Peponocephala electra) are a tropical delphinid that primarily inhabits open-ocean waters and is known to feed on mesopelagic squid and fish (Best and Shaughnessy 1981, Clarke and Young 1998). In Hawaiian waters, these whales are encountered relatively infrequently. Around the main Hawaiian Islands, two populations have been identified: a "main Hawaiian Islands" population and a population resident to the island of Hawai' $i$ (Aschettino et al. 2011). As part of a multispecies study examining movements and habitat use of cetaceans around the main Hawaiian Islands (e.g., Schorr et al. 2009, Baird et al. 2010), individual melonheaded whales from the "main Hawaiian Islands" population have been instrumented with satellite tags for various purposes (e.g., Baird et al. 2008b), including to assess their movements in relation to mesoscale eddies, to determine whether they use offshore eddy systems as foraging habitat.

To test the hypothesis that movements of melon-headed whales leaving the vicinity of the main Hawaiian Islands will be influenced by offshore eddy systems, we analyzed satellite telemetry data from 10 melon-headed whales in conjunction with output from the Hybrid Coordinate Ocean Model (HYCOM) Hawai' i regional model (http://apdrc.soest.hawaii.edu/REGMOD).

Details on the satellite tags and deployment system were presented by Schorr $e t$ al. (2009) and are only briefly discussed here. The Low Impact Minimally Percutaneous External-electronics Transmitter (LIMPET) tags (Andrews et al. 2008, Schorr et al. 2009, Baird et al. 2010) deployed were location-only SPOT5 (Wildlife Computers, Redmond, WA) Argos-linked platform transmitter terminals, which attached to the dorsal fin using two $4.5 \mathrm{~cm}$ long medical-grade titanium darts with backwards facing barbs that acted as anchors for the darts (see Andrews et al. 2008). Tags were deployed remotely using a Dan-Inject JM Special 25 (Børkop, Denmark) pneumatic projector with a modified arrow to hold the tag in flight at a range of 3-6 m.

Age class of tagged individuals was characterized in the field based on relative body size as "adult" or "juvenile." Tagged individuals were photographed and photos were 
compared to a photo-identification catalog (see Aschettino et al. 2011) to determine population identity.

We used the Douglas Argos-Filter (available at http://alaska.usgs.gov/science/ biology/spatial/douglas.html), version 7.06, to assess locations for plausibility using two independent methods; distance between consecutive locations, and rates and bearings among consecutive movement vectors (see Schorr et al. 2009). The user-defined variable of maximum-redundant distance (temporally near-consecutive points within a defined distance that are kept by the filter) was set at $3 \mathrm{~km}$, maximum rate of movement was set to $20 \mathrm{~km} / \mathrm{h}$, Argos class 2 and 3 locations were always retained, and a rate coefficient of 25 was selected. The rate coefficient algorithm takes into account that the farther an animal moves between locations, the less likely it is to return to, or near to, the original location without any intervening positions, creating an acute angle characteristic of typical Argos error. Results discussed below use only locations that passed these filtering parameters. From these locations, only the position(s) with the best location class for each day were used. On days when there were multiple positions with the best location class, the positions were averaged to obtain one daily position.

Tracks were broken into nearshore and offshore components. Offshore components began on the first day when all subsequent positions were in waters deeper than $3,000 \mathrm{~m}$. A depth of 3,000 $\mathrm{m}$ was used based on the steeply sloping bathymetry around the Hawaiian Islands and because it resulted in the clearest separation between track segments that remained offshore and segments that returned to shore. Bathymetry data are described in Smith and Sandwell (1997).

Daily sea surface height (SSH) and currents with $0.08^{\circ}$ resolution from the HYCOM Hawai i regional model were examined. Horizontal gradients in both variables were used to identify eddies. In this study, HYCOM data were used in place of AVISO satellite data as the former are available daily and the latter only as weekly means (http:// www.aviso.oceanobs.com/en/data/products/sea-surfaceheight-products/global/index.html). Additionally, AVISO SSH and current data have only a $0.3^{\circ}$ resolution. The finer spatial and temporal resolution offered by the HYCOM output allowed for more detailed analyses of the melon-headed whaleselected habitat. HYCOM assimilates satellite altimetry and therefore should represent the mesoscale features observed in the AVISO SSH data well. To confirm this, the daily HYCOM SSH data were regridded to AVISO's $0.3^{\circ}$ resolution and weekly means calculated for the time and area spanned by the recorded melon-headed whale tracks. These regridded means were well correlated with the AVISO data $(r=0.88)$, as were the regridded daily HYCOM values with AVISO weekly means $(r=0.85)$.

A Kolmogorov-Smirnov (KS) test was used to investigate whether melon-headed whales selected a significantly different environment than the surrounding area. As discussed by Kobayashi et al. (2008), the KS test compares two cumulative distributions by using the maximum vertical distance between the two distributions as the test statistic. If the distribution of the specific oceanographic variable along the track is significantly different than that of the surrounding area (defined below), it can be inferred that the animal is selecting its habitat based on the variable being examined. 
KS tests were performed with both horizontal surface current magnitude and surface vertical velocity. Horizontal current magnitude, $|\bar{V}|$, is defined as:

$$
|\bar{V}|=\sqrt{\left|u^{2}+v^{2}\right|}
$$

where $u$ and $v$ are the zonal and meridional components of the surface current, respectively. Distributions of these variables coinciding with the offshore track positions were compared to distributions of those in the surrounding area within defined bounding limits. Each daily track position was compared with the HYCOM output for the corresponding date, and these daily data were aggregated to form the track and surrounding area distributions used in the KS tests. The track distributions include only data from grid cells encompassing daily track positions. Surrounding area distributions include all remaining data within the bounded surrounding area. The latitudinal limits of the bounded surrounding area were chosen such that they included the area where the melon-headed whales could have traveled and were set as follows:

$$
\text { MaxLat }_{\text {SA }}=\text { MaxLat }_{\text {Track }}+0.5 \text { (MaxSpan) }
$$

$$
\text { MinLat }_{\text {SA }}=\text { MinLat }_{\text {Track }}-0.5(\text { MaxSpan }),
$$

where MaxSpan represents the greater of either the total latitudinal or longitudinal distance spanned by the offshore portion of the track. The same method was used to determine the minimum and maximum longitude of the surrounding area. Longitudinal distances were calculated in kilometers at the mean latitude for the offshore portion of the track. To test the sensitivity of the KS test, values of both 0.25(MaxSpan) and 0.75 (MaxSpan) were tested as well.

Tracks ranged from 7 to $24 \mathrm{~d}(\overline{\mathrm{x}}=15 \mathrm{~d}$; SD $=5 \mathrm{~d})$ and from 172 to $1,140 \mathrm{~km}(\overline{\mathrm{x}}=$ $627 \mathrm{~km} ; \mathrm{SD}=319 \mathrm{~km}$ ) in length. All tagged whales were classified as adults. Five of the whales' tracks (tagged in four different groups) contained offshore components (Table 1, Fig. 1), while the remaining five were entirely nearshore. The offshore track components ranged from 4 to $16 \mathrm{~d}(\overline{\mathrm{x}}=9 \mathrm{~d} ; \mathrm{SD}=5 \mathrm{~d})$ and from 160 to $819 \mathrm{~km}$ $(\overline{\mathrm{x}}=463 \mathrm{~km} ; \mathrm{SD}=283 \mathrm{~km})$ in length. Although two of the five whales were tagged within the same group, they remained together only when nearshore and separated for the offshore portion of their tracks (Tracks 1 and 2, Fig. 1).

Two tracks near the edges of cyclonic eddies were characterized by greater $|\bar{V}|$ than the surrounding area (Tracks 4 and 5, Fig. 2A-D, Table 1), while the opposite was true of the track near the center of an anticyclonic eddy (Track 3, Fig. 2E-F, Table 1). Sensitivity tests using both 0.25 (MaxSpan) and 0.75 (MaxSpan) also yielded significant results $\left(1.6 \times 10^{-3} \leq P \leq 4.7 \times 10^{-2}\right)$ for tracks 3,4 , and $5(0.47 \leq P \leq$ 0.9) for tracks 1 and 2). Thus, we feel bounding the KS test area by 0.5(MaxSpan) adequately represents the area the melon-headed whales could have selected for transit. KS tests on vertical currents were insignificant. 
Table 1. Details of all melon-headed whale tracks with an offshore segment. Numbers in parentheses indicate start dates and lengths for the offshore segment of the track. The mean horizontal current magnitude $|\bar{V}|$ is shown for the offshore track and bounded surrounding area, excluding the offshore track, used in the KS test.

\begin{tabular}{|c|c|c|c|c|c|c|c|}
\hline \multirow[b]{2}{*}{ Track } & \multirow[b]{2}{*}{$\begin{array}{l}\text { Start date } \\
\text { (offshore) }\end{array}$} & \multirow[b]{2}{*}{ End date } & \multirow[b]{2}{*}{$\begin{array}{c}\text { Length }(\mathrm{km}) \\
\text { (offshore) }\end{array}$} & \multirow[b]{2}{*}{$\begin{array}{l}\% \text { Time } \\
\text { offshore }\end{array}$} & \multicolumn{3}{|c|}{ Mean $|\bar{V}|(\mathrm{m} / \mathrm{s})$} \\
\hline & & & & & Track & $\begin{array}{l}\text { Excluding } \\
\text { track }\end{array}$ & KS $P$-value \\
\hline 1 & $\begin{array}{c}19 \text { Apr } 08 \\
\text { (02 May 08) }\end{array}$ & 12 May 08 & $1,140(551)$ & 46 & 0.26 & 0.23 & 0.66 \\
\hline 2 & $\begin{array}{l}19 \text { Apr } 08 \\
(25 \text { Apr } 08)\end{array}$ & 28 Apr 08 & $557(187)$ & 40 & 0.18 & 0.23 & 0.59 \\
\hline 3 & $\begin{array}{l}25 \text { Jun } 08 \\
\text { (29 Jun 08) }\end{array}$ & $14 \mathrm{Jul} 08$ & 889 (819) & 80 & 0.16 & 0.23 & $1.8 \times 10^{-2}$ \\
\hline 4 & $\begin{array}{c}\text { 02 Jul 08 } \\
\text { (12 Jul 08) }\end{array}$ & $20 \mathrm{Jul} 08$ & $1,061(599)$ & 47 & 0.29 & 0.17 & $3.2 \times 10^{-2}$ \\
\hline 5 & $\begin{array}{c}10 \text { Dec } 08 \\
\text { (20 Dec } 08)\end{array}$ & 24 Dec 08 & $543(160)$ & 33 & 0.36 & 0.22 & $5.3 \times 10^{-3}$ \\
\hline
\end{tabular}

Both statistical and visual examination of the offshore portion of three melonheaded whale tracks show that melon-headed whales around the main Hawaiian Islands that move offshore occupy the edges of cold core cyclonic eddies and the centers of warm core anticyclonic eddies, presumably for foraging purposes (Fig. 2). Visual inspection confirmed that the melon-headed whale tracks were indeed coincident with these specific eddy regions, while statistical analysis was used to test whether the currents in these regions were significantly different than those in the surrounding area. Convergence zones in cyclonic and anticyclonic eddies are marked by strong and weak currents, respectively, eliminating the possibility that these regions were instead chosen for physical characteristics such as a preferred surface

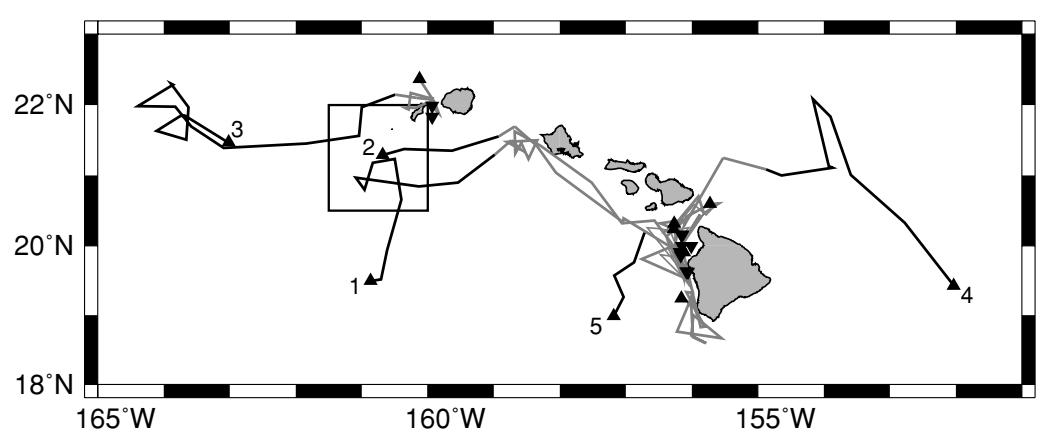

Figure 1. Tracks of all 10 melon-headed whales from the main Hawaiian Islands population with nearshore portions in gray and offshore portions in black. Downward-pointing triangles represent tag-deployment positions while upward-pointing triangles represent final recorded track positions. The five offshore tracks are numbered near their final recorded track positions. The rectangle represents the boundaries of the Ni'ihau Box. 

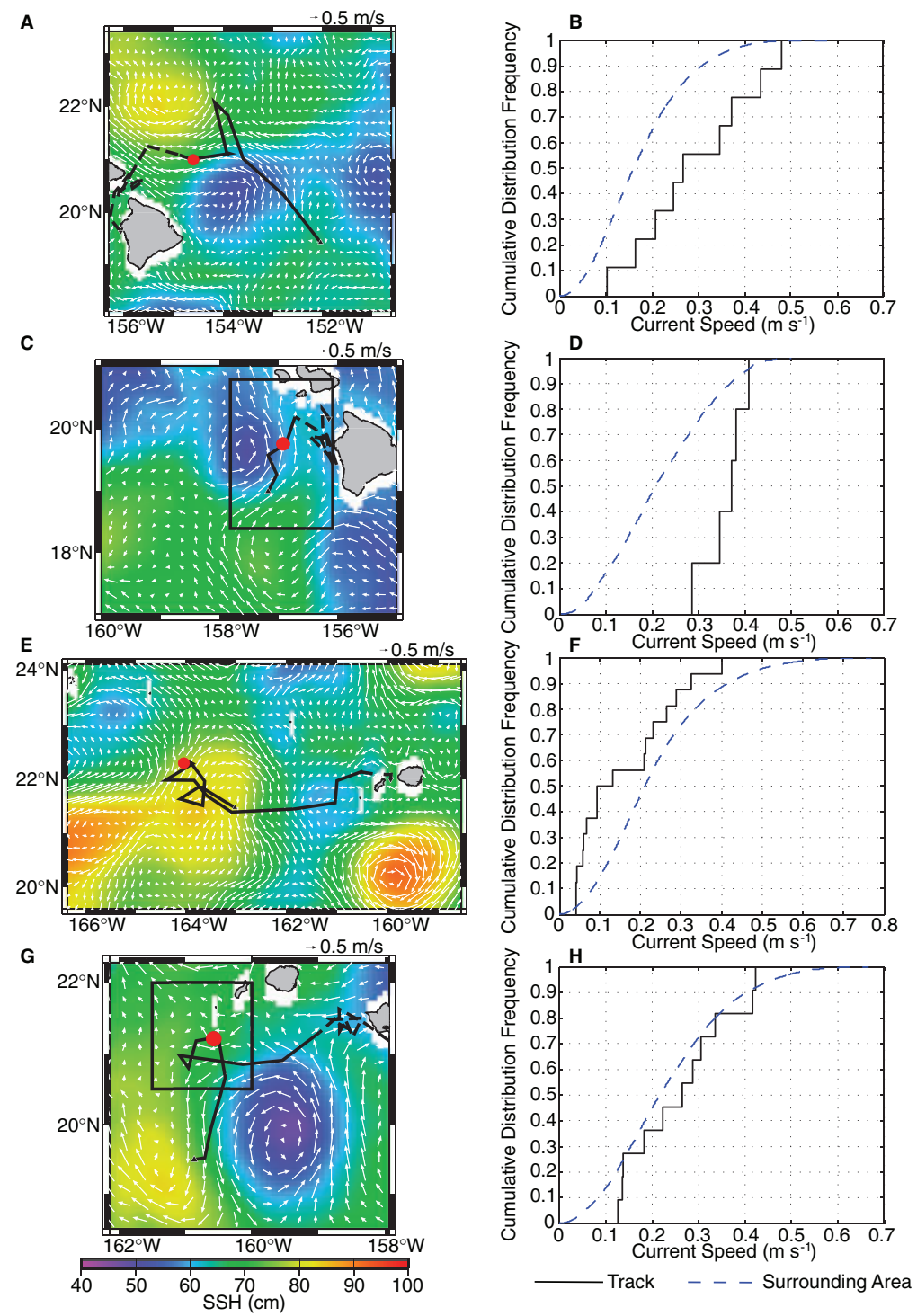

Figure 2. Melon-headed whale tracks 4 (A), 5 (C), 3 (E), and 1 (G) and HYCOM SSH (color) and surface currents (vectors) for 13 July 2008, 21 December 2008, 8 July 2008, and 9 May 2008, respectively. The nearshore segment of the track is represented by a dotted line, offshore by solid. The cyclonic eddies with which the tracks 4, 5, and 1 are associated are indicated by low $\mathrm{SSH}(<65 \mathrm{~cm})$ and cyclonic rotation in the surface currents. The anticyclonic eddy with which track 3 is associated is indicated by high SSH $(>75 \mathrm{~cm})$. The red circle designates the position of the melon-headed whale on the day coinciding with the HYCOM output. Triangles as in Figure 1. Area shown in (A), (E), and (G) represents area enclosed by KS test bounding limits. Rectangle in $(\mathrm{C})$ represents area enclosed by KS test bounding limits. Box in $(G)$ indicates the Ni i ihau Box. Both track (black solid) and nontrack surrounding area (blue dashed) cumulative distributions used in the KS test are shown for tracks 4 (B), 5 (D), $3(\mathrm{~F})$, and $1(\mathrm{H})$. 
current. Both warm and cold core eddies are continually recurring features in the lee of the Hawaiian Islands. Wind stress from easterly trade winds is intensified by the islands' topography, leading to the formation of eddies. These eddies then propagate northwestward (Patzert and Wyrtki 1974, Vaillancourt et al. 2003). To the south of the islands, the westward-flowing north equatorial current generates and sustains westward and northwestward moving eddies as well (Holland and Mitchum 2001). The melon-headed whale tracks also indicate a potentially favorable habitat southwest of the Hawaiian island of Ni'ihau (Fig. 1), although the factors contributing to this area's desirability are unclear.

Two melon-headed whale tracks were characterized by their association with the edges of cyclonic eddies; one spending 4 of its 5 offshore days in this edge region and another 6 of its 9 offshore days (Tracks 4 and 5, Fig. 2A-D). Visual inspection confirms that both tracks associated with cyclonic eddies were associated with the outer edge region. This edge region is marked by greater currents than the eddy center, as can be seen in Figure 2. Additionally, this edge region is characterized by convergence of nutrients and phytoplankton upwelled in the eddy's divergent center. Several studies identify this convergence zone as a fruitful foraging ground for species such as sea turtles, marlin and tuna, seabirds, and cetaceans (Davis et al. 2002, Seki et al. 2002, Bakun 2006, Polovina et al. 2006, Yen et al. 2006). Seki et al. (2002) discussed the shift in the area of highest catch in the 1995 Hawaiian International Billfish Tournament. During this particular tournament, the area of highest catch shifted from its historic location to the region coincident with the convergence zone at the edge of a cyclonic eddy (Seki et al. 2002). Additional investigations of eddies in the lee of the Hawaiian Islands show them to be areas containing greater concentrations of nutrients and phytoplankton (Seki et al. 2001, Bidigare et al. 2003, Vaillancourt et al. 2003). Presumably, this leads to a concentration of higher trophic level species as well.

One offshore melon-headed whale track was associated with the center of an anticyclonic eddy, as identified by the significantly slower current speeds associated with the track positions (Track 3, Fig. 2E-F). Twelve of the 16 offshore days were spent near this area of surface convergence. Several studies suggest that anticyclonic eddies are a less favorable foraging habitat for pelagic marine species than cyclonic eddies (McGillicuddy and Robinson 1997, Davis et al. 2002, Bakun 2006). However, in their study of seabird associations with oceanic eddies, Yen et al. (2006) found a correlation between several species and both cyclonic and anticyclonic eddies. The authors attributed this correlation, in part, to the aggregation of mid trophic level prey such as fish and squid that occurs in the convergence zones of the eddies (Yen et al. 2006). Both Howell et al. (2010) and Polovina et al. (2006) reported associations between loggerhead sea turtles (Caretta caretta) and warm core anticyclonic eddies, though unlike the melon-headed whale track discussed above, the loggerhead positions were mostly coincident with the eddy edges.

Visual inspection of the five offshore tracks also identified a noneddy-associated area southwest of $\mathrm{Ni}$ ihau, bounded approximately by $161.5^{\circ} \mathrm{W}, 160^{\circ} \mathrm{W}, 20.5^{\circ} \mathrm{N}$, and $22^{\circ} \mathrm{N}$, that we term the "Ni ihau Box" (Fig. 1). No clear motivating factor could be found to explain why these animals moved through this area. Seasonality could 
Table 2. Details on melon-headed whale tracks in relation to the $\mathrm{Ni}^{\text {' } i h a u ~ B o x ~(s e e ~ t e x t) . ~}$

\begin{tabular}{lccc}
\hline \hline Track & $\begin{array}{c}\text { Days } \\
\text { offshore }\end{array}$ & $\begin{array}{c}\text { Days inside Ni'ihau Box } \\
\text { (\% of offshore time) }\end{array}$ & $\begin{array}{c}\text { Days outside Ni'ihau Box } \\
\text { (\% of offshore time) }\end{array}$ \\
\hline 1 & 11 & $6(55)$ & $5(45)$ \\
2 & 4 & $2(50)$ & $2(50)$ \\
3 & 16 & $2(12.5)$ & $14(87.5)$ \\
\hline
\end{tabular}

not be adequately investigated as the three tracks spanned only 4 mo (April-July 2008). KS tests investigating portions of the tracks inside and outside the $\mathrm{Ni}$ ' ihau Box separately were insignificant, suggesting that neither horizontal nor vertical currents were a motivating factor. Bathymetry was also ruled out as all offshore track positions were in waters with depths greater than $3,000 \mathrm{~m}$. However, the fact that all three westward-moving melon-headed whales independently transited this area warrants further investigation. Additionally, of the three melon-headed whales that transited into or through the $\mathrm{Ni}$ ihau Box, two spent at least half their offshore time in this area, one deviating from the periphery of a cyclonic eddy to do so (Table 2, Track 1, Fig. 2G-H).

This study is the first to use satellite telemetry data to gain insight into the pelagic habitat of melon-headed whales. Examining melon-headed whale tracks in conjunction with HYCOM model output of daily SSH and sea surface currents indicates that when melon-headed whales move away from the coastal waters of Hawai' $i$ they move offshore into statistically distinct environments. These environments coincide with the convergence areas of both cyclonic and anticyclonic eddies, indicating that they are likely selected for foraging purposes. Additionally, all westward-moving melonheaded whales moved into or through a small area southwest of $\mathrm{Ni}$ 'i ihau for reasons that are not yet apparent. The information gained through this study may also indicate pelagic habitats that are favorable foraging grounds for other cetaceans as well.

\section{ACKNOWLEDGMENTS}

Field efforts were funded by the U.S. Navy through the Southwest Fisheries Science Center, NMFS, NOAA; Scripps Institution of Oceanography; and Woods Hole Oceanographic Institution, and also supported by the Wild Whale Research Foundation. The authors thank Jessica Aschettino for examining photos of tagged and companion whales to assess population identity and Yanli Jia and the International Pacific Research Center for providing the HYCOM output. This article was improved substantially by the reviews of Evan Howell, Don Kobayashi, Erin Oleson, and several anonymous reviewers. Tagging was undertaken under National Marine Fisheries Service Scientific Research Permit No. 731-1774 issued to RWB.

\section{Literature Cited}

Andrews, R. D., R. L. Pitman and L. T. Ballance. 2008. Satellite tracking reveals distinct movement patterns for Type B and Type C killer whales in the southern Ross Sea. Antarctic Polar Biology 31:1461-1468.

Aschettino, J. M., R. W. Baird, D. J. McSweeney, et al. 2011. Population structure of melon-headed whales (Peponocephala electra) in the Hawaiian Archipelago: Evidence of multiple populations based on photo-identification. Marine Mammal Science. DOI: $10.1111 / j .1748-7692.2011 .00517 . x$ 
Baird, R. W., A. M. Gorgone, D. J. McSweeney, et al. 2008a. False killer whales (Pseudorca crassidens) around the main Hawaiian Islands: Long-term site fidelity, inter-island movements, and association patterns. Marine Mammal Science 24:591-612.

Baird, R. W., G. S. Schorr, D. L. Webster, D. J. McSweeney, M. B. Hanson and R. D. Andrews. 2008b. Multi-species cetacean satellite tagging to examine movements in relation of the 2008 Rim-of-the-Pacific (RIMPAC) naval exercise. A quick look report on the results of tagging efforts undertaken under Order No. D1000115 from the Woods Hole Oceanographic Institution. Available at http://www.cascadiaresearch.org/hawaii/publications. htm.

Baird, R. W., G. S. Schorr, D. L. Webster, D. J. McSweeney, M. B. Hanson and R. D. Andrews. 2010. Movements of satellite-tagged false killer whales around the main Hawaiian Islands. Endangered Species Research 10:107-121.

Bakun, A. 2006. Fronts and eddies as key structures in the habitat of marine fish larvae: Opportunity, adaptive response, and competitive advantage. Scientia Marina 70S2: 105-122.

Barlow, J. 2006. Cetacean abundance in Hawaiian waters estimated from a summer/fall survey in 2002. Marine Mammal Science 22:446-464.

Best, P. B., and P. D. Shaughnessy. 1981. First record of the melon-headed whale, Peponocephala electra, from South Africa. Annals of the South African Museum 83:33-47.

Bidigare, R. R., C. Benitez-Nelson, C. L. Leonard, P. D. Quay, M. L. Parsons, D. G. Foley and M. P. Seki. 2003. Influence of a cyclonic eddy on microheterotroph biomass and carbon export in the lee of Hawaii. Geophysical Research Letters 30:13181321.

Clarke, M., and R. Young. 1998. Description and analysis of cephalopod beaks from stomachs of six species of odontodete cetaceans stranded on Hawaiian shores. Journal of the Marine Biological Association of the United Kingdom 78:623-341.

Davis, R. W., J. G. Ortega-Ortiz, C. A. Ribic, et al. 2002. Cetacean habitat in the northern oceanic Gulf of Mexico. Deep-Sea Research Part I 49:121-142.

Holland, C. L., and G. T. Mitchum. 2001. Propagation of Big Island eddies. Journal of Geophysical Research 106:935-944.

Howell, E. A., P. H. Dutton, J. J. Polovina, H. Bailey, D. M. Parker and G. H. Balazs. 2010. Oceanographic influences on the dive behavior of juvenile loggerhead turtles (Caretta caretta) in the North Pacific Ocean. Marine Biology 157:1011-1026.

Kobayashi, D. R., J. J. Polovina, D. M. Parker, et al. 2008. Pelagic habitat characterization of loggerhead sea turtles, Caretta caretta, in the North Pacific Ocean (1997-2006): Insights from satellite tag tracking and remotely sensed data. Journal of Experimental Marine Biology and Ecology 356:96-114.

McGillicuddy, D. J., and A. R. Robinson. 1997. Eddy-induced nutrient supply and new production in the Sargasso Sea. Deep-Sea Research Part I 44:1427-1450.

Patzert, W. C., and K. Wyrtki. 1974. Anticyclonic flow around the Hawaiian Islands indicated by current meter data. Journal of Physical Oceanography 4:673-676.

Polovina, J. J., I. Uchida, G. Balazs, E. A. Howell, D. Parker and P. Dutton. 2006. The Kuroshio extension bifurcation region: A pelagic hotspot for juvenile loggerhead sea turtles. Deep-Sea Research Part II 53:326-339.

Schorr, G. S., R. W. Baird, M. B. Hanson, D. L. Webster, D. J. McSweeney and R. D. Andrews. 2009. Movements of satellite-tagged Blainville's beaked whales off the island of Hawai'i. Endangered Species Research 10:203-213.

Seki, M. P., J. J. Polovina, R. E. Brainard, R. R. Bidigare, C. L. Leonard and D. G. Foley. 2001. Biological enhancement at cyclonic eddies tracked with GOES thermal imagery in Hawaiian waters. Geophysical Research Letters 28:1583-1586.

Seki, M. P., R. Lumpkin and P. Flament. 2002. Hawaiian cyclonic eddies and blue marlin catches: The case study of the 1995 Hawaiian International Billfish Tournament. Journal of Oceanography 58:739-745.

Smith, W. H. F., and D. T. Sandwell. 1997. Global seafloor topography from satellite altimetry and ship depth soundings. Science 277:1956-1962. 
Vaillancourt, R. D., J. Marra, M. P. Seki, M. L. Parsons and R. R. Bidigare. 2003. Impact of a cyclonic eddy on phytoplankton community structure and phyotosynthetic competency in the subtropical North Pacific Ocean. Deep-Sea Research Part I 50:829-847.

Yen, P. P. W., W. J. Sydeman, S. J. Bograd and K. D. Hyrenbach. 2006. Spring-time distribution of migratory marine birds in the southern California Current: Oceanic eddy associations and coastal habitat hotspots over 17 years. Deep-Sea Research Part II 53:399-418.

Received: 24 September 2010

Accepted: 1 May 2011 